\title{
Description of ST Segments Elevation of Myocardial Infarction on Patients Undergoing Primary Percutaneous Coronary Intervention in dr. M. Djamil Hospital Padang
}

\author{
${ }^{1}$ Pradita Diah Permatasari, ${ }^{2}$ Muhammad Fadil, ${ }^{3}$ Masrul Syafri \\ ${ }^{1}$ Cardiology and Vascular Medicine Residence, Medical Faculty of Andalas University, Indonesia \\ ${ }^{2,}{ }^{3}$ Cardiology and Vascular Medicine Department, Medical Faculty of Andalas University, dr. M. Djamil \\ Hospital, Indonesia \\ Coresponding author: Pradita Diah Permatasari, e-mail: praditadiahp@gmail.com \\ Co-author: MF: mfadil98@yahoo.com, MS: drmasrulsyafri@gmail.com \\ Submitted: 16/03/2020 Revised: 02/04/2020 Accepted: 19/04/2020 Published online: 21/04/2020
}

doi: https://doi.org/10.35308/j-kesmas.v7i1.1817 How to cite this article: Permatasari, P.D., Fadil, M., \& Syafri, M. (2020).

Description of ST segments elevation of myocardial infarction on patients undergoing primary percutaneous coronary

intervention in dr. M. Djamil Hospital Padang. J-Kesmas: Jurnal Fakultas Kesehatan Masyarakat (The Indonesian Journal of Public Health), 7(1): 1-5.

\begin{abstract}
Myocardial infarction is influenced by various risk factors consist of gender, age, family history, smoking, hypertension, dyslipidemia, diabetes mellitus and menopause. The aim of this study was to describe the description of sex, age and risk factors possessed by patients with ST segments Elevation Myocardial Infarction (STEMI) who underwent primary percutaneous coronary intervention (PPCI) procedures at Dr. M. Djamil hospital Padang. Amount of 40 people were obtained specifically for STEMI patients who underwent PPCI and were treated at the integrated heart services installation of RSUP dr. M. Djamil Padang from July-September 2019. The research variables measured were age, sex, risk factors for hypertension, diabetes mellitus, smokers, dyslipidemia, family history and menopause. Data was analyzed in the form of univariate analysis, which explained each research variable according to the proportion and frequency values. The results were found in 40 patients with acute ST segments elevation myocardial infarction, all aged $>40$ years, most were male (85\%) and the most risk factor was smoking $(82,5 \%)$. We conclude that STEMI patients who underwent PPCI in dr.M. Djamil hospital Padang from JulySeptember 2019 were all $>40$ years old, most were male, with the most risk factors were smokers.
\end{abstract}

Keywords: ST segments elevation; myocardial infarction; primary percutaneous coronary intervention.

\section{Introduction}

Acute myocardial infarction is one of the main causes of death in the world and is associated with poor prognosis. The incidence of STEMI in Europe ranges from around 43 to 144 cases per 100,000 population per year. Whereas in the United States reported incidents ranged from 50 cases per 100,000 population per year in 2008 (Ibanez et al., 2018). In Indonesia in 2013 according to the Ministry of Health there were around 478,000 patients diagnosed with coronary heart disease with the prevalence of STEMI increasing from $20 \%$ to $40 \%$ of myocardial infarction (RISKESDAS, 2013). Although improving the management quality of acute myocardial infarction in the last decade has reduced mortality rates, the risk of complications of heart failure, death and cardiovascular complications after myocardial infarction is still difficult to predict (Dong et al., 2015). dr. M. Djamil hospital found 62 STEMI patients who underwent PPCI from July 2018 to November 2018 with an incidence of acute heart failure during treatment of $17.7 \%$, arrhythmias $9.6 \%$, cardiogenic shock $8 \%$ and $6.4 \%$ died.

Data from the National Health Survey of the Ministry of Health of the Republic of Indonesia shows that heart and blood vessel disease is one of the main causes of death in Indonesia. Analysis of the Jakarta Acute Coronary Syndrome (JAC) registry conducted at the Harapan Kita National Heart Center emergency department in 2008-2009 which included 2103 acute coronary syndrome patients (654 STEMI patients) showed that the majority of STEMI patients $(59 \%)$ did not get acute reperfusion therapy and 52\% of patients were referred inter-hospital (Dharma, 2017).

The main mechanism of STEMI is the process of acute thrombosis due to rupture of atherosclerotic plaque which causes a sudden blockage of coronary blood flow. The process of acute thrombosis begins with cracks in the walls of the diseased arteries that occur due to loss of integrity of the plaque cap. Cracks or gaps in plaque rupture cause exposure to subendothelial matrix elements such as collagen, 
platelet activation and thrombus formation. Furthermore, tissue factor is released by the injured artery, which activates the extrinsic coagulation cascade and triggers fibrin formation. If an occlusive thrombus is formed, the patient will experience ST segment elevation myocardial infarction (Topol \& Werf, 2007).

Cellular effects of ischemia occur within a few seconds after the onset of hypoxia with loss of production of adenosine triphosphate (ATP). Relaxation and contraction of the myocardium will be disrupted, irreversible cell injury will begin in twenty minutes. Necrosis will be complete within six hours unless reperfusion occurs or extensive collateral circulation appears. STEMI is a clinical syndrome that is defined as a symptom of myocardial ischemia, ST segment elevation on two paired electrocardiogram leads, and an increase in biomarkers that signifies myocardial necrosis (Scirica \& Morrow, 2015; O'Gara et al., 2013).

Immediate reperfusion therapy, either with primary or pharmacologic percutaneous coronary intervention is indicated for all patients with symptoms that arise within twelve hours accompanied by persistent ST segment elevation or new left bundle branch block. In certain cases, surgical reperfusion therapy (Coronary Artery Bypass Graft) can be a therapeutic option. The main goal of immediate reperfusion therapy is to bring back the coronary blood flow to an ischemic myocardium, resulting in better patient outcomes (Hass et al., 2011; Tobing, 2017). Our research goal was to describe the description of sex, age and risk factors possessed by patients with ST segments Elevation Myocardial Infarction (STEMI) who underwent primary percutaneous coronary intervention (PPCI) procedures at Dr. M. Djamil hospital Padang.

\section{Materials and Methods}

The author uses a descriptive research design with a document analysis approach to obtain useful information about the description of STEMI patients undergoing PPCI. Information was obtained specifically for STEMI patients who underwent PPCI who were treated at the integrated heart services installation of RSUP dr. M. Djamil Padang from July-September 2019. The total number of patients is 40 people.

The research variables measured were age, sex, risk factors for hypertension, diabetes mellitus, smokers, dyslipidemia, family history and menopause. Age is defined as the life span of a patient which is calculated from the time he was born until the stated research is carried out by years. Sex is defined as a physical sign that is identified in patients and carried from birth, differentiated by male and female. Hypertension is defined as a condition in which a person has systolic blood pressure $\geq 140$ $\mathrm{mmHg}$ and or diastolic blood pressure $\geq 90 \mathrm{mmHg}$, on repeated examinations or obtaining antihypertensive therapy (Piepoli et al., 2016). Diabetes mellitus is defined as a group of metabolic diseases with hyperglycemia that occurs due to abnormal insulin secretion, insulin work or both. The diagnostic criteria are based on fasting plasma glucose $\geq 126 \mathrm{mg}$ / dl, plasma glucose $\geq 200 \mathrm{mg}$ / dl 2 hours after oral glucose tolerance test with 75 gram glucose load, random plasma glucose $\geq 200 \mathrm{mg} / \mathrm{dl}$ with classic complaints, HbA1c $\geq 6.5 \%$ (Soelistijo et al., 2015). Smokers are defined as habits that are valued based on nonsmoking and smoking habits which are assessed based on the number of cigarettes smoked each day. Smokers are defined as people who smoke more than 100 cigarettes during their lifetime and still smoke until now or stop in less than a year (Kang et al., 2003). Dyslipidemia is defined as a condition in which the results of measuring serum cholesterol levels meet one or more criteria in the form of cholesterol total $>200 \mathrm{mg} / \mathrm{dl}$, LDL cholesterol $>100 \mathrm{mg} / \mathrm{dl}$, HDL cholesterol $<40$ $\mathrm{mg} / \mathrm{dl}$, triglyceride $1 \geq 150 \mathrm{mg} / \mathrm{dl}$, receiving antidyslipidemia therapy (Piepoli et al., 2016). Family history is defined as a history of premature cardiovascular disease (disease incidence fatal/nonfatal) or/and diagnosis of cardiovascular disease in one or more family members at the first degree male family members less than 65 years old or first-degree female family members less than 55 years old (Piepoli et al., 2016). Menopause is permanent discontinuation of menstruation due to loss of activity of ovarian follicular.

Data analysis was carried out in the form of univariate analysis, which explained each research variable according to the proportion and frequency values. Data was presented in the form of a frequency table so that it can be known the proportion of categories of each variable. Calculation of the proportion value using the following formula:

$\mathrm{P}=\stackrel{\mathrm{n}}{----\mathrm{X} 100}$

$\mathrm{P}$ : proportion value, $\mathrm{n}$ : number of samples in a certain category, $\mathrm{N}$ : the total number of samples.

\section{Results}

There were 40 patients suffering from STEMI who underwent PPCI from July to September 2019. 
Of the 40 patients, all $>40$ years old, most were male and the most risk factor was smoking. We describe that in 40 patients with acute ST segments elevation myocardial infarction, all aged $>40$ years, most were male $(85 \%)$ and the most risk factor was smoking $(82,5 \%)$ as shown in Table 1 .

Table-1: Characteristics of STEMI patients underwent PPCI

\begin{tabular}{ll}
\hline Basic Characteristics & n (f \%) \\
\hline Age $>40$ years old & $40(100 \%)$ \\
$\quad<40$ years old & $0(0 \%)$ \\
Sex & \\
Male & $34(85 \%)$ \\
Female & $6(15 \%)$ \\
Hypertension & $20(50 \%)$ \\
Yes & $20(50 \%)$ \\
No & $7(17.5 \%)$ \\
Diabetes mellitus & $33(82.5 \%)$ \\
Yes & $33(82.5 \%)$ \\
No & $7(17.5 \%)$ \\
Smoker & \\
Yes & $13(32.5 \%)$ \\
No & $27(67.5 \%)$ \\
Dyslipidemia & \\
Yes & $1(2.5 \%)$ \\
No & $39(97.5 \%)$ \\
Family History & $6(15 \%)$ \\
Yes & $34(85 \%)$ \\
No &
\end{tabular}

\section{Discussion}

In this study, all patients $>40$ years old were found. This is in accordance with the research of previously report from GRACE and CONCORDANCE data in australia which found the median age of patients experiencing STEMI which is 61 years (52 years-69 years) (Vernon et al., 2019). This is consistent with a population study conducted by Jousilahti et al., (1999) who found that the incidence rate of coronary heart disease was three times greater in men than women and mortality rate was five times greater in men than women. Smoking also increases the risk of coronary heart disease in men (Jousilahti et al., 1999). Hypertension can cause coronary heart disease. Hypertension is associated with some metabolic disorders, such as hyperinsulinemia and dyslipidemia which are risk factors for atherosclerosis event. Lipid deposition and the formation of atherosclerotic plaque can be triggered by increased transmural pressure in the arteries accompanied by increased mechanical stress and endothelial permeability, which in turn will cause endothelial dysfunction (Escobar, 2002). Diabetes mellitus is associated with impaired platelet function and activity, adhesion and aggregation that caused platelet hyperreactivity, eventually leading to endothelial dysfunction. Diabetic patients have a greater incidence of atherosclerosis and multivessel coronary artery disease (Dąbek et al., 2016).

It is well known that cigarette smoking contained toxic substances cause environmental pollution into atmosphere. Water and soil pollution also contaminate by the cigarette butts that contained many toxic chemicals. People, animals, and plants are affected by contact or absorb the toxic substances from the cigarette residues. Smoking is the biggest cause of preventable deaths in the world. It can damage nearly every organ in the body. Indeed, Yarmaliza \& Farisni (2018) and Syahputri et al. (2019) described that in protecting public health from the dangers of cigarette smoke, West Aceh Government increased awareness and passed local low regulation namely Qanun Number 14 of 2015 in concerning non-smoking areas that regulates nonsmoking areas to realize the highest degree of public health in West Aceh Regency.

Smoking has a negative effect on the hemostatic process which causes an imbalance between protrombotic and antithrombotic factors which will further initiate and propagate coronary artery disease and thrombosis, smoking can also reduce HDL levels. Higher smoking habits in men also become one cause of increased incidence of coronary heart disease in men (Jousilahti et al., 1999). The hormone estrogen which is the main hormone in women has a cardioprotective effect through metabolism of glucose, the hemostatic system and has a direct effect on the function of endothelial cell (Grady et al., 1992; Shahar et al., 1996). Decreased estrogen production after menopause changes the metabolism of lipid in women to be more atherogenic by lowering HDL levels and increasing LDL, total cholesterol, triglycerides and lipoproteins (a) (Matthews et al., 1989; Bonithon-Kopp et al., 1990).

\section{Conclusion}

In this study, it was found that STEMI patients who underwent PPCI in dr. M. Djamil hospital Padang from July-September 2019 were all > 40 years old, most were male, with the most risk factors were smokers.

We suggest that further research with a better design in multicenter to evaluate the risk factors of STEMI patients underwent PPCI especially the risk factors that can be modified. 


\section{Acknowledgement}

The authors received no specific funding for this work. We hereby thank the Cardiology and Vascular Medicine Department Medical Faculty of Andalas University and dr. M. Djamil Hospital which have supported this research and also we would like to thank the patients who are willing to participate as the respondents and all parties who involved in this study.

\section{Author Contribution and Competing Interest}

All of the authors contributed in collecting and analyzing the data, including preparing the manuscript. Pradita Diah Permatasari acted as the chief researcher and as the corresponding author. MF and MS acted as mentor in collecting and analyzing the data. There was no competing interest related to the conduct of this study.

\section{Publisher's Note}

J-Kesmas: Jurnal Fakultas Kesehatan Masyarakat (Indonesia Journal of Public Health) remains neutral with regard to jurisdictional claims in published institutional affiliation.

\section{References}

Bonithon-Kopp, C., Scarabin, P.Y., Darne, B., Malmejak, A. \& Guize, L. (1990) Menopause-related changes in lipoproteins and some other cardiovascular risk factors. Int. J. Epidemiol., 19:42-8.

Dąbek, J., Bałys M, Majewski, M. \& Gąsior, Z.T. (2016) Diabetic patients with an acute myocardial infarction in terms of risk factors and comorbidities management: characteristics of the highest-risk individuals. Advances Clin. Experiment. Med., 25(4): 655-663.

Dharma, S. (2017) Infark miokard akut disertai elevasi segmen ST: Patologi, patofisiologi dan gambaran klinis. In: Yuniadi, Y, Hermanto, DY, Siswanto, BB. Buku Ajar Kardiovaskular Jilid 2 (pp.153-9). Jakarta, Indonesia: Sagung Seto.

Dong, Y.M., Liu, X.X., Wei, G.Q., Da, Y.N., Cha, L. \& Ma, C.S. (2015) Prediction of long-term outcome after acute myocardial infarction using circulating miR-145. Scand. J. Clin. Labor. Investigat., 75(1): 85-91.

Escobar, E. (2002) Hypertension and coronary heart disease. J. Human Hypert., 16(1): S61-S63.

Grady, D., Rubin, S.M., Petitti, D.B., Fox, C.S., Black, D., Ettinger, B, Ernster, V.L. \& Cummings, S.R. (1992) Hormone therapy to prevent disease and prolong life in post menopausal women. Ann. Intern. Med., 117: 1016-1037.

Hass, E.E., Yang, E.H., Gersh, B.J., \& O’Rourke, R.A.
(2011) ST-segment elevation myocardial infarction. In: Hurst's The Heart Volume Two. $13^{\text {th }}$ edition (pp.1361-1364). United States: McGraw-Hill.

Ibanez, B., James, S., Agewall, S., Antunes, M.J., Bucciarelli-Ducci, C., Bueno, H., Caforio, A.L.P., Crea, F., Goudevenos, J.A., Halvorsen, S., Hindricks, G., Kastrati, A., Lenzen, M.J., Prescott, E., Roffi, $\quad$ M., Valgimigli, M., Varenhorst, C., Vranckx, P., \& Widimský, P. (2018) 2017 ESC Guidelines for the management of acute myocardial infarction in patients presenting with ST-segment elevation: The Task Force for the management of acute myocardial infarction in patients presenting with ST-segment elevation of the European Society of Cardiology (ESC). Eur. Heart J., 39(2): 119-177.

Jousilahti, P, Vartiainen, E., Tuomilehto, J. \& Puska, P. (1999) Sex, Age, Cardiovascular Risk Factors, and Coronary Heart Disease A Prospective Follow-Up Study of 14786 Middle-Aged Men and Women in Finland. Circulation, 99: 1165-1172.

Kang, M.J., Oh, Y.M., Lee, J.C., Kim, D.G., Park, M.J., Lee, M.G., Hyun, I.G., Han, S.K., Shim, Y.S. \& Jung, K.S. (2003) Lung Matrix Metalloproteinase-9 Correlates with Cigarette Smoking and Obstruction of Airflow. Korean Med. Sci., 12: 821-827.

Matthews, K.A., Meilahn, E., Kuller, L.H., Kelsey, S.F., Caggiula, A.W., \& Wing, R.R. (1989) Menopause and risk factors for coronary heart disease. N. Engl. J. Med., 321: 641- 646.

O'Gara, P.T., Kushner, F.G., Ascheim, D.D., Casey, D.E., Jr. Chung, M.K., de Lemos, J.A., Ettinger, S.M., Fang, J.C., Fesmire, F.M., Franklin, B.A., Granger, C.B., Krumholz, H.M., Linderbaum, J.A., Morrow, D.A., Newby, L.K., Ornato, J.P., Ou, N., Radford, M.J., Tamis-Holland, J.E., Tommaso, C.L., Tracy, C.M., Woo, Y.J., Zhao, D.X., Anderson, J.L., Jacobs, A.K., Halperin, J.L., Albert, N.M., Brindis, R.G., Creager, M.A., DeMets, D., Guyton, R.A., Hochman, J.S., Kovacs, R.J., Kushner, F.G., Ohman, E.M., Stevenson, W.G. \& Yancy, C.W. (2013). 2013 ACCF/AHA Guideline for the Management of ST-Elevation Myocardial Infarction: A Report of the American College of Cardiology Foundation/American Heart Association Task Force on Practice Guidelines. Circulation, 127(4): e362-e425.

Piepoli, M.F., Hoes, A.W., Agewall, S., Albus, C., Brotons, C., Catapano, A.L., Cooney, M.T., Corrà, U., Cosyns, B., Deaton, C., Graham, I., Hall, M.S., Hobbs, $\quad$ F.D.R., Løchen, M.L., Löllgen, H., Marques-Vidal, P., Perk, J., Prescott, E., Redon, J., Richter, D.J., Sattar, N., Smulders, Y., Tiberi, M., van der Worp, H.B., van Dis, I., Verschuren, W.M.M., Binno, S. (2016) 2016 European guidelines on cardiovascular disease prevention in clinical practice: The Sixth Joint Task Force of the European Society of Cardiology and Other Societies on Cardiovascular 
Disease Prevention in Clinical Practice (constituted by representatives of 10 societies and by invited experts) Developed with the special contribution of the European Association for Cardiovascular Prevention \& Rehabilitation (EACPR). Eur. Heart $J ., 37(29)$ : 2315-2381.

RISKESDAS. (2013) Badan Penelitian dan Pengembangan Kesehatan. Riset Kesehatan Dasar (RISKESDAS). $L$ nas, 1-384.

Scirica, B.M. \& Morrow, D.A. (2015) ST-elevation myocardial infarction: pathology, pathopysiology, and clinical features. In: Braunwald's Heart Disease. A Textbook of Cardiovascular Medicine. Tenth edition (pp.1072-88). Philadelphia, United States: Elsevier.

Shahar, E., Folsom, A.R., Salomaa, V.V., Stinson, V.L., McGovern, P.G., Shimakawa, T., Chambless, L.E. \& Wu, K.K. (1996) Relation of hormonereplacement therapy to measures of plasma fibrinolytic activity. Atherosclerosis Risk in Communities (ARIC) Study Investigators. Circulation, 93(11):1970-75.

Soelistijo, S.A., Novida, H., Rudijanto, A., Suastika, K. \& Manaf, A. (2015) Definisi, pathogenesis, klasifikasi diabetes mellitus. Konsensus pengelolaan dan pencegahan diabetes mellitus tipe 2 di Indonesia 2015 (pp.6-11). Jakarta, Indonesia, PB. PERKENI.
Syahputri, V.N., Fitriani, F., Farisni, T.N., Yarmaliza, Y., Reynaldi, F. \& Darmawi, D. (2019) The implementation of non-smoking area qanun (regulation) in West Aceh Health Office. J-Kesmas: Jurnal Fakultas Kesehatan Masyarakat (Indones. J. Pub. Health), 6(2): 57-73.

Tobing, D. (2017) Tatalaksana infark miokard elevasi segmen ST. In: Yuniadi, Y, Hermanto, DY, Siswanto, BB. Buku Ajar Kardiovaskular Jilid 2 (pp.166-70). Jakarta, Indonesia, Sagung Seto.

Topol, E.J. \& Werf, F.J.V. (2007) Acute myocardial infarction: early diagnosis and management. In: Topol, EJ. Textbook of Cardiovascular Medicine. $3^{\text {rd }}$ edition (pp.280-1). Philadelphia, United States: Lippincott Williams and wilkins.

Vernon, S. T., Coffey, S., D'Souza, M., Chow, C. K., Kilian, J., Hyun, K. \& Figtree, G. A. (2019) ST Segment-Elevation Myocardial Infarction (STEMI) Patients Without Standard Modifiable Cardiovascular Risk Factors - How Common Are They, and What Are Their Outcomes? J. Am. Heart Assoc., 8(21):e013296.

Yarmaliza, Y. \& Farisni, T.N. (2018) Evaluasi Penerapan Kawasan Tanpa Rokok Melalui Peran Dinas Kesehatan. J-Kesmas: Jurnal Fakultas Kesehatan Masyarakat (Indones. J. Pub. Health), 5(1): 25-36. 